Pesq. Vet. Bras. 30(11):918-920, novembro 2010

\title{
Detection and dynamics of porcine circovirus 2 shedding in semen using conventional and real-time PCR ${ }^{1}$
}

\author{
Priscilla F. Gerber², Flávia F. Pinto², Marcos B. Heinemann² \\ and Zélia I.P. Lobato ${ }^{*}$
}

\begin{abstract}
Gerber P.F., Pinto F.F., Heinemann M.B. \& Lobato Z.I.P. 2010. Detection and dynamics of porcine circovirus type 2 in semen using conventional and real time PCR. Pesquisa Veterinária Brasileira 30(11):918-920. Laboratório de Pesquisa em Virologia Animal, Departamento de Medicina Veterinária Preventiva, Universidade Federal de Minas Gerais, Avenida. Antônio Carlos 6627, Belo Horizonte, MG 30123-970, Brazil. E-mail: ziplobato@vet.ufmg.br

The dynamics of porcine circovirus type 2 (PCV2) shedding in semen of naturally infected boars was studied. Semen was collected serially each 15 or 20 days during 62 days from 5 boars from a herd and from 11 boars from an artificial insemination center. All boars were positive for PCV2 DNA by nested polymerase chain reaction of raw semen in at least two sampling dates, and most of them had detectable shedding in all sampling dates. Real-time quantitative PCR was performed in 23 samples. All samples showed low amounts of PCV2 DNA, ranging from 98 to 652 PCV2 copies $/ \mathrm{mL}$. No differences between the frequencies of PCV2 DNA shed in semen were found considering herds and age of boars. PCV2 shedding in the semen can occur continuously or intermittently up to 60 days in naturally infected boars at 12 to 42 months old in absence of PCV2 clinical signs. These results demonstrate sporadic and long-term shedding patterns of low amounts of PCV2 DNA in semen from naturally infected boars.
\end{abstract}

INDEX TERMS: Artificial insemination, boar, PCR, porcine circovirus type 2, semen.

RESUMO.- [Deteccão e dinâmica de excreção do circovírus porcino tipo 2 no semen pelo PCR convencional e PCR em tempo real.] A dinâmica da excreção do circovírus suíno tipo 2 (CVS2) em sêmen de machos naturalmente infectados foi estudada. Amostras de sêmen de cinco machos de um plantel e de 11 machos de um centro de inseminação artificial foram coletadas a cada 15 ou 20 dias durante 62 dias. Todos os machos testados foram positivos para a presença do DNA viral no sêmen em pelo menos duas coletas, sendo que a maioria deles eliminou o CVS2 em todas as coletas. O teste de PCR quantitativa em tempo real foi aplicado em 23 amostras. Todas as amostras tinham baixa quantidade de DNA viral, variando de 98 a 652 cópias de CVS2/ml. Não houve diferença na freqüência de eliminação do DNA viral levando em conta os plantéis e

\footnotetext{
${ }^{1}$ Received on October 29, 2009.

Accepted for publication on July 22, 2010.

2 Laboratório de Pesquisa em Virologia Animal, Departamento de Medicina Veterinária Preventiva, Escola de Veterinária, Universidade Federal de Minas Gerais, Av. Antônio Carlos 6627, Belo Horizonte, MG 30123-970, Brazil. * Corresponding author: ziplobato@ vet.ufmg.br
}

idade dos machos. A excreção do CVS2 no sêmen pode ocorrer de forma contínua ou intermitente por mais de 60 dias em machos de 12 a 42 meses de idade naturalmente infectados na ausência de sinais clínicos de CVS2. Estes resultados demonstram padrões esporádico e de longa duração de excreção viral em pequenas quantidades no sêmen de varrões naturalmente infectados.

TERMOS DE INDEXAÇÃO: Inseminação artificial, varrão, PCR, circovírus suíno tipo 2 , sêmen.

\section{INTRODUCTION}

Porcine circovirus type 2 (PCV2) is a widespread, circular, single-stranded DNA virus recognized as the causal agent of porcine circovirus-associated diseases (PCVADs) postweaning multisystemic syndrome (PMWS). The disease has been reported worldwide, associated with considerable economic losses in the pig industry due to increase in mortality and production of non-marketable pigs (Opriessnig et al. 2007).

Transmission of PCV2 occurs through direct contact via oronasal, fecal, and urinary routes (Opriessnig et al. 2007). 
Vertical transmission can occur by transplacental spread of PCV2 leading to embryonic death, mummification, abortion and/or viremic piglets at birth (Rose et al. 2007). Although shedding of PCV2 DNA was found intermitted in the semen of naturally and experimentally infected pigs (Larochelle et al. 2000, Mclntosh et al. 2006) little is known about the role of PCV2 in semen and the potential risk of dissemination of the virus via this route.

The extensive practice of artificial insemination in the swine industry for introducing new genetics and for biosecurity reasons requires monitoring boar centers to prevent diseases transmission (Guerin \& Pozzi 2005), and determination of the PCV2 status of boar semen is required (Pal et al. 2008).

This study investigates the dynamics of PCV2 shedding in semen of naturally infected boars from a commercial herd and an insemination center in Brazil.

\section{MATERIALS AND METHODS}

Samples. Semen samples were obtained from five 12 to 42 month-old boars from a commercial herd, and eleven 18 to24month-old boars from an insemination center (AIC). All boars were clinically healthy at the time of this investigation. Semen samples were collected at intervals of 15-20 days throughout the 62-day observation period.

Sample handling. From each ejaculate, $2 \mathrm{ml}$ of raw semen were placed into a sterile plastic tube and immediately frozen at $-20^{\circ} \mathrm{C}$ until use. Cell and seminal plasma semen fractions were separated following centrifugation of raw semen at $12,000 \times g$ for 30 seconds and the supernatant was passed by a Sephacryl S-400 (Pharmacia Bio- tech, Uppsala, Sweden) column and were stored at $-80^{\circ} \mathrm{C}$ until further processing.

Nested PCR. DNA was extracted as described elsewhere (Sambrook et al. 1989). Primers and amplification conditions for nested PCR (nPCR) were carried out as previous described by Larochelle et al. (2000). For first and second (nested) PCR, primer pairs PCVI forward (52-GCC AGT TCG TCA CCC TTT C-32) and PCVI reverse (52-CTC CCG CAC CTT CGG ATA T32), and PCVII forward (52-TAG GTT AGG GCT GTG GCC TT32) and PCVII reverse (52-CCG CAC CTT CGG ATA TAC TG32) were used, respectively. The temperature-time profiles for first and second PCR, respectively, were: initial denaturation at $94^{\circ} \mathrm{C} / 2 \mathrm{~min}$, followed by 35 cycles of $95^{\circ} \mathrm{C} / 1 \mathrm{~min}, 64^{\circ} \mathrm{C} / 1 \mathrm{~min}$, $72^{\circ} \mathrm{C} / 1 \mathrm{~min}$ and a final extension at $72^{\circ} \mathrm{C} / 7 \mathrm{~min}$ (first $\mathrm{PCR}$ ), initial denaturation at $94^{\circ} \mathrm{C} / 2 \mathrm{~min}$, followed by 20 cycles of $94^{\circ} \mathrm{C} / 30 \mathrm{~s}$, $64^{\circ} \mathrm{C} / 30 \mathrm{~s}, 72^{\circ} \mathrm{C} / 30 \mathrm{~s}$ and a final extension at $72^{\circ} \mathrm{C} / 7 \mathrm{~min}$ (nested PCR). A negative (aqua bidestillatum) and a positive control (PCV2 positive tissue from a pig that died from PMWS) were included in each PCR series. PCR products were visualized after electrophoresis on $1 \%$ agarose gels, stained with ethidium bromide.

Quantitative PCR (qPCR). DNA-extracts of all semen samples collected from Pigs 1, 3, 6, 7, 8 and 13 were used for quantification of PCV2 genomic DNA by SYBR Green real-time PCR as described previously (Mclntosh et al. 2009). Briefly, reactions were carried out in a 96-well plate including five 20fold log dilutions of PCV2 standard (108 to 100), and a negative control (with autoclaved water as a template) by duplicates. Each reaction contained $100 \mathrm{nM}$ of each primer, $12.5 \mu \mathrm{l}$ of SYBR Green Master Mix (Applied Biosystems, Foster City, CA, USA) and 2.5 $\mu$ Lof template. Autoclaved ultrapure water was added to $25 \mu \mathrm{L}$. Amplification was carried out under Universal Cycling conditions $\left(10 \mathrm{~min}\right.$ at $95^{\circ} \mathrm{C}, 2 \mathrm{~min}$ at $50^{\circ} \mathrm{C}$ and 40 cycles of $15 \mathrm{~s}$ at $95^{\circ} \mathrm{C}, 1 \mathrm{~min}$ at $60^{\circ} \mathrm{C}$ ). Amplification and quantification was carried out in an ABIPRISM 7500 Sequence Detection System (Applied Biosystems, Foster City, CA, USA). Viral concentrations were expressed as the mean viral DNA copy numbers per milliliter of seminal plasma.

Statistical analysis. The proportion of PCV2 PCR positive semen sample in each group was compared with the Fisher exact test. Relationships between boars ages and viral load in qPCR were examined using Spearman's correlation. Differences with $P<0.05$ were considered significant.

\section{RESULTS AND DISCUSSION}

All 16 boars were positive for PCV2 DNA in semen by nPCR in at least two collections, during a period of up to 62 days. PCV2 was detected in 55 of 60 semen samples (91\%) (Table 1). Five boars shed PCV2 DNA in semen intermittently but 11 animals $(68.7 \%)$ were positive in all collected samples. A similar shedding pattern was previously observed in experimentally (Larochelle et al. 2000) and in naturally infected boars (McIntosh et al. 2006). In the last paper, the frequency of PCV2 DNA in semen was low and sporadic, with 30/903 (3.3\%) positive semen samples from 13/43 $(30.2 \%)$ boars. In other reports PCV2 DNA in semen samples was detected in 28/60 (47\%) in Korea (Kim et al. 2001) and 86/472 (18\%) in Austria and Germany (Schmoll et al. 2008), what might indicate a different pathogen pressure under different situations.

We found low amounts of PCV2 DNA in seminal plasma samples, ranging from 98 to 652 PCV2 copies/mL (Fig.1). In a recent qPCR study, Pal et al. (2008) found that most of

Table 1. Detection of PCV2 DNA in semen from 16 boars collected every 15-20 days

\begin{tabular}{cccccccc}
\hline Boars $\begin{array}{c}\text { Age } \\
\text { (months) }\end{array}$ & \multicolumn{5}{c}{ Sample collection } & $\mathrm{P}^{*}$ & Total \\
\cline { 2 - 6 } & 1 & 2 & 3 & 4 & 5 & & \\
\hline
\end{tabular}

\begin{tabular}{ccccccccc}
\hline \multicolumn{7}{c}{ On-farm semen collected } & & \\
1 & 28 & $\mathrm{P}$ & $\mathrm{P}$ & $\mathrm{P}$ & $\mathrm{P}$ & $\mathrm{P}$ & 5 & 5 \\
2 & 12 & $\mathrm{P}$ & $\mathrm{P}$ & - & $\mathrm{N}$ & $\mathrm{P}$ & 3 & 4 \\
3 & 34 & $\mathrm{P}$ & $\mathrm{P}$ & $\mathrm{P}$ & - & $\mathrm{P}$ & 4 & 4 \\
4 & 42 & $\mathrm{P}$ & $\mathrm{N}$ & $\mathrm{P}$ & - & $\mathrm{P}$ & 3 & 4 \\
5 & 18 & $\mathrm{P}$ & - & $\mathrm{P}$ & $\mathrm{P}$ & $\mathrm{P}$ & 4 & 4
\end{tabular}

Artificial insemination center

\begin{tabular}{rrrrrrrrr}
\multicolumn{7}{c}{ Artificial insemination center } & & \\
6 & 18 & $\mathrm{P}$ & $\mathrm{P}$ & - & $\mathrm{P}$ & - & 3 & 3 \\
7 & 20 & $\mathrm{P}$ & $\mathrm{P}$ & $\mathrm{P}$ & - & $\mathrm{P}$ & 4 & 4 \\
8 & 22 & - & $\mathrm{P}$ & - & $\mathrm{P}$ & $\mathrm{P}$ & 3 & 3 \\
9 & 24 & - & $\mathrm{P}$ & $\mathrm{P}$ & - & $\mathrm{P}$ & 3 & 3 \\
10 & 24 & $\mathrm{P}$ & $\mathrm{P}$ & - & $\mathrm{P}$ & $\mathrm{P}$ & 4 & 4 \\
11 & 22 & - & $\mathrm{N}$ & $\mathrm{P}$ & $\mathrm{P}$ & $\mathrm{P}$ & 3 & 4 \\
12 & 20 & - & $\mathrm{P}$ & $\mathrm{P}$ & - & $\mathrm{P}$ & 3 & 3 \\
13 & 18 & $\mathrm{P}$ & $\mathrm{P}$ & - & $\mathrm{P}$ & $\mathrm{P}$ & 4 & 4 \\
14 & 18 & $\mathrm{~N}$ & $\mathrm{P}$ & - & $\mathrm{N}$ & $\mathrm{P}$ & 2 & 4 \\
15 & 18 & $\mathrm{P}$ & - & $\mathrm{P}$ & $\mathrm{P}$ & - & 3 & 3 \\
16 & 24 & $\mathrm{P}$ & $\mathrm{P}$ & - & $\mathrm{P}$ & $\mathrm{P}$ & 4 & 4 \\
Total & & & & & & & 56 & 60
\end{tabular}

${ }^{*} \mathrm{P}=$ positive, $\mathrm{N}=$ negative, - = sample not tested. 


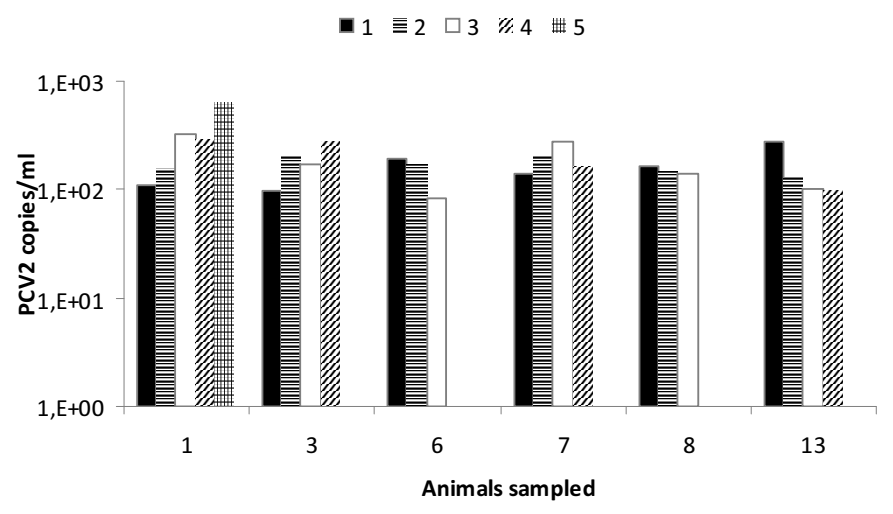

Fig.1. Quantification of PCV2 in plasma seminal samples from boars at sample collections 1 to 5 .

the PCV2 DNA was associated with the cell fractions (ranging from 207 to $70,747 \mathrm{PCV} 2$ copies $/ \mathrm{mL}$ ) rather than with the plasma (ranging from 268 to $14,711 \mathrm{PCV} 2$ copies $/ \mathrm{mL}$ ). The differences between PCV2 DNA amounts in those studies could be partially explained by DNA extraction and reduction of naturally PCR-inhibiting substances in semen in the latter study. However, Madson et al. (2009) determined that low doses of PCV2 (10 $5.6-10^{5.8}$ PCV2 copies $/ \mathrm{mL}$ ) in semen used for artificial insemination would not cause reproductive failure, seroconversion, or PCV2 viremia in naïve gilts and their offspring. Taking together, these results indicate that PCV2 transmission via semen of naturally infected boars would not be an important infection source in swine herd.

In this study, no differences between the frequency of PCV2 DNA shed in semen was found considering the age or boars used for on-farm or AIC semen collection (Table 1). This contrast with others studies which indicate that semen samples were more likely to be PCV2 DNA positive in boars younger than 16 months of age; boars older than 13 months of age was 2.6 less likely to shed PCV2 DNA in semen than younger boars (McIntosh et al. 2006, Schmoll et al. 2008). Differences among studies may be due, at least in part, to the imbalance of this study in terms of age of boars, or due to the limited number of animals nonrepresentative for the prevalence of PCV2 in semen of boars in Al centers or farms. However, Mclntosh et al. (2006) found that of the 43 boars tested, $73.3 \%$ of the PCV2 positive semen tests came from five boars, which might indicate that PCV2 is able to persist in some boars revealing marked differences in individual PCV2 DNA shedding patterns in boars from same stud. Monitoring PCV2 in semen may be required for commercial AIC supplying semen to PCV2-susceptible sows.

The transmission of several viruses through the semen has been documented and this have great importance to the swine industry, since contaminated semen becomes a potential spreading of agents in the animal population, especially with the wide usage of artificial insemination (Guerin \& Pozzi 2005).

\section{CONCLUSION}

This study demonstrates that the PCV2 shedding in the semen can occur in low amounts up to 60 days in naturally infected 12 to 42-month-old boars in absence of PCV2 clinical signs.

Acknowledgements.- To FAPEMIG and CNPq for the financial support. Zélia I.P. Lobato has a fellowship from CNPq.

\section{REFERENCES}

Guerin B. \& Pozzi N. 2005. Viruses in boar semen: Detection and clinical as well as epidemiological consequences regarding disease transmission by artificial insemination. Theriogenology 63:556-572.

Kim J., Han D.U., Choi C. \& Chae C. 2001. Differentiation of porcine circovirus (PCV)-1 and PCV-2 in boar semen using a multiplex nested polymerase chain reaction. J. Virol. Methods 98:25-31.

Larochelle R., Bielanski A., Muller P. \& Magar R. 2000. PCR detection and evidence of shedding of Porcine circovirus type 2 in boar semen. J. Clin. Microbiol. 38:4629-4632.

Madson D.M., Ramamoorthy S., Kuster C., Pal N., Meng X.J., Halbur P.G. \& Opriessnig T. 2009. Infectivity of porcine circovirus type 2 DNA in semen from experimentally-infected boars. Vet. Res. 40:10.

McIntosh K.A., Harding J.C., Parker S., Ellis J.A. \& Appleyard G.D. 2006. Nested polymerase chain reaction detection and duration of porcine circovirus type 2 in semen with sperm morphological analysis from naturally infected boars. J. Vet. Diagn. Invest. 18:380-384.

Mclntosh K., Tumber A., Harding J., Krakowka S., Ellis J. \& Hill J. 2009. Development and validation of a SYBR green real-time PCR for the quantification of porcine circovirus type 2 in serum, buffy coat, feces, and multiple tissues. Vet. Microbiol. 133:23-33.

Opriessnig T., Meng X.J. \& Halbur P.G. 2007. Porcine circovirus type 2-associated disease: Update on current terminology, clinical manifestations, pathogenesis, diagnosis, and intervention strategies. J. Vet. Diagn. Invest. 19:591-615.

Pal N., Huang Y.W., Madson D.M., Kuster C., Meng X.J., Halbur P.G. \& Opriessnig T. 2008. Development and validation of a duplex realtime PCR assay for the simultaneous detection and quantification of porcine circovirus type 2 and an internal control on porcine semen samples. J. Virol. Methods 149:217-225.

Rose N., Blanchard P., Cariolet R., Grasland B., Amenna N., Oger A., Durand B., Balasch M., Jestin A. \& Madec F. 2007. Vaccination of porcine circovirus type 2 (PCV2)-infected sows against porcine Parvovirus (PPV) and Erysipelas: Effect on post-weaning multisystemic wasting syndrome (PMWS) and on PCV2 genome load in the offspring. J. Comp. Pathol. 136:133-44.

Sambrook J., Fritsch E.F. \& Maniatis T. 1989. Molecular Cloning: A laboratory manual. Vol.3. $3^{\text {rd }}$ ed. Cold Spring Harbor Laboratory, New York, p.A8.9-A8.21.

Schmoll F., Lang C., Steinrigl A.S., Schulze K. \& Kauffold J. 2008. Prevalence of PCV2 in Austrian and German boars and semen used for artificial insemination. Theriogenology 69:814-821. 